\title{
Differing Semaphorin 3A Concentrations Trigger Distinct Signaling Mechanisms in Growth Cone Collapse
}

\author{
Richard P. C. Manns, Geoffrey M. W. Cook, Christine E. Holt, and Roger J. Keynes \\ Department of Physiology, Development, and Neuroscience, University of Cambridge, Cambridge CB2 3DY, United Kingdom
}

\begin{abstract}
Semaphorin-3A (Sema3A) is a major guidance cue in the developing nervous system. Previous studies have revealed a dependence of responses to Sema3A on local protein synthesis (PS) in axonal growth cones, but a recent study has called this dependence into question. To understand the basis of this discrepancy we used the growth cone collapse assay on chick dorsal root ganglion neurons. We show that the dependence of growth cone collapse on protein synthesis varies according to Sema3A concentration, from near-total at low concentration $(<100 \mathrm{ng} / \mathrm{ml})$ to minimal at high concentration $(>625 \mathrm{ng} / \mathrm{ml})$. Further, we show that neuropilin-1 (NP-1) mediates both PSdependent and PS-independent collapse. Our findings are consistent with the operation of at least two distinct Sema3A signaling pathways: one that is PS-dependent, involving mammalian target of rapamycin, and one that is PS-independent, involving GSK- $3 \beta$ activation and operative at all concentrations of Sema3A examined. The results provide a plausible explanation for the discrepancy in PS-dependence reported in the literature, and indicate that different signaling pathways activated within growth cones can be modulated by changing the concentration of the same guidance cue.
\end{abstract}

\section{Introduction}

While dendritic protein synthesis is known to be crucial for regulating spine dynamics and synaptic plasticity (Martin and Zukin, 2006; Schuman et al., 2006; Bourne and Harris, 2008), the significance of axonal protein synthesis (PS) was controversial until recently. During the last decade, the importance of axonal PS has been highlighted in growth cone guidance and in axon regeneration (Lin and Holt, 2007; Park et al., 2008; Donnelly et al., 2010). Proteins synthesized locally in the axon account for only 5\% of total axonal protein (Eng et al., 1999), and their significance in growth and guidance has been debated. Although mRNAs for cytoskeletal proteins were among those first detected in axons (Kaplan et al., 1992), PS inhibition does not affect the rate of axon growth in the short term (Eng et al., 1999; Campbell and Holt, 2001). Further, although $\beta$-actin is a crucial neuronal cytoskeletal protein, isolated axons grow without local PS (Eng et al., 1999). Similarly, work by Leung et al. (2006) suggests that localized syn-

Received Nov. 30, 2011; revised April 27, 2012; accepted May 5, 2012.

Author contributions: R.P.C.M., G.M.W.C., C.E.H., and R.J.K. designed research; R.P.C.M., G.M.W.C., and R.J.K. performed research; R.P.C.M., G.M.W.C., C.E.H., and R.J.K. analyzed data; R.P.C.M., G.M.W.C., C.E.H., and R.J.K. wrote the paper.

This work was funded by a project grant from the Wellcome Trust and a graduate studentship to R.P.C.M. from Trinity College, Cambridge, United Kingdom. We thank Louis Leung and Byung C. (Jason) Yoon for invaluable advice in this project, and Sarah Awan for helpful discussion of her preliminary work. We also thank James Blundell, Clare Ellis, Liz Muir, Mansoor Raza, and Kate Wiles for assistance with some of the experiments, and Cláudio Roque for advice on the use of $\mathrm{L}$-azidohomoalanine for monitoring protein synthesis.

The authors declare no competing financial interests.

This article is freely available online through the J Neurosci Open Choice option.

Correspondence should be addressed to Dr. Roger Keynes, Anatomy Building, Department of Physiology, Development, and Neuroscience, University of Cambridge, Downing Street, Cambridge CB2 3DY, UK. E-mail: rjk10@cam.ac.uk.

DOI:10.1523/JNEUROSCI.5964-11.2012

Copyright $\odot 2012$ the authors $\quad 0270-6474 / 12 / 328554-06 \$ 15.00 / 0$ thesis of cytoskeletal proteins directs growth cone polarity and motility but not outgrowth.

Campbell and Holt (2001) first identified a direct role for local PS in axon guidance, and several groups have reported supporting evidence for this mechanism in the growth cone, for example the presence of active mRNA localization (Bassell et al., 1998), mRNA-specific transport (Aronov et al., 2001) and phosphorylation-dependent mRNA release (Sasaki et al., 2010). Further, recent genome-wide unbiased studies have revealed thousands of mRNA transcripts in axon growth cones with cell-type and developmental-stage-specific localization (Taylor et al., 2009; Andreassi et al., 2010; Zivraj et al., 2010; Gumy et al., 2011).

Notwithstanding the presence of $\beta$-actin and RhoA mRNAs in the growth cone, the ability of external cues to influence localization and synthesis, and the sufficiency of localized synthesis to cause growth cone turning (Wu et al., 2005; Leung et al., 2006; Yao et al., 2006), their relevance has been questioned by Roche et al. (2009), apparently contradicting several studies (Campbell and Holt, 2001; Li et al., 2004; Wu et al., 2005). Roche et al. (2009) investigated the role of PS in mediating responses to several molecular cues using outgrowth, turning and growth cone collapse assays, and concluded that axon guidance mechanisms do not require protein synthesis, despite replicating findings showing that semaphorin-3A (Sema3A) activates PS. We have therefore examined Sema3A-induced growth cone collapse in chick dorsal root ganglion (DRG) explants (Luo et al., 1993), a model also used by Roche et al. (2009), aiming to identify reasons for their inability to replicate previous findings. We show that collapse is indeed refractory to PS-inhibition when using high concentrations of Sema3A that induce an extensive degree of collapse in these explants, but it is not refractory at lower Sema3A concentrations. The mammalian target of rapamycin (mTOR)-dependent pathway operates at lower Sema3A 
A

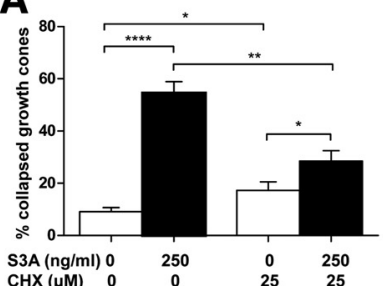

C

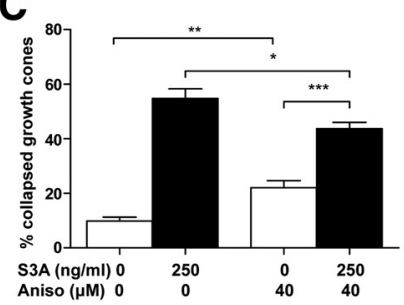

E

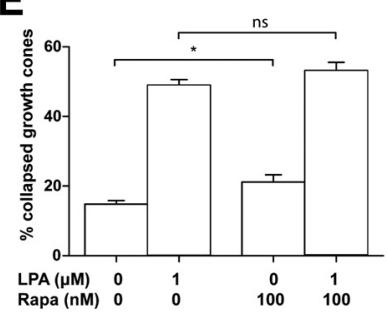

G

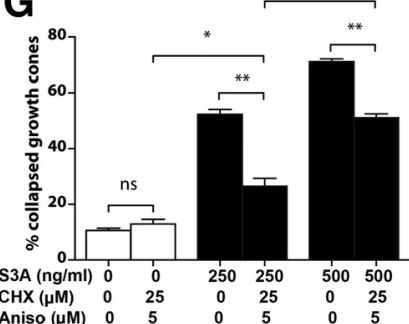

I

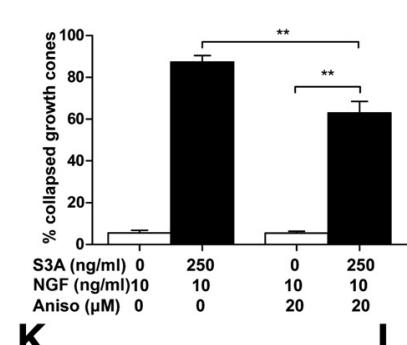

K

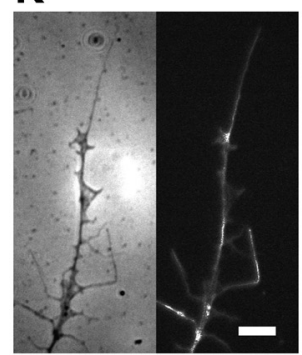

L

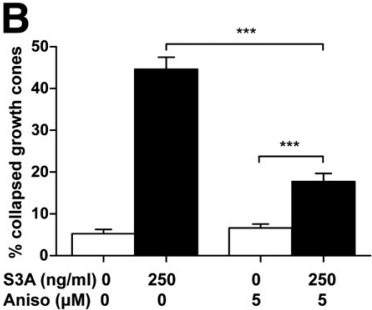

D

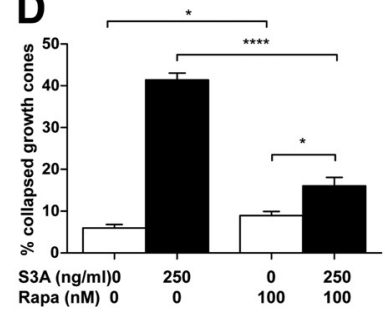

F

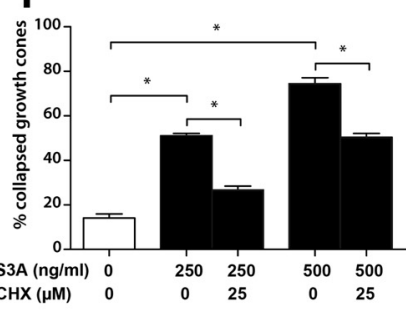

$\mathbf{H}$

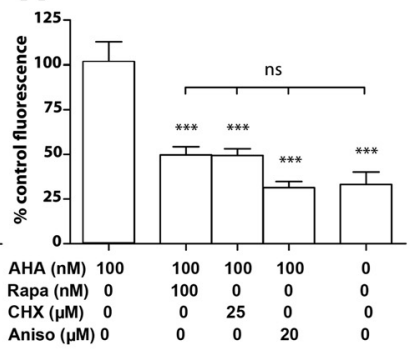

$\mathbf{J}$

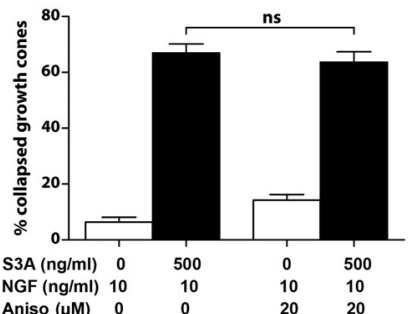

Figure 1. Effect of protein synthesis inhibition on Sema3A (S3A)-induced collapse. $\boldsymbol{A}-\boldsymbol{D}$, The ribosomal inhibitors cycloheximide (CHX, $25 \mu \mathrm{m}, \boldsymbol{A}$ ) and anisomycin (Aniso, $5 \mu \mathrm{M}, \boldsymbol{B} ; 40 \mu \mathrm{M}, \mathrm{C}$ ), and the mTOR inhibitor rapamycin (Rapa, $100 \mathrm{~nm}, \boldsymbol{D})$ reduce the extent of collapse (mean \pm SEM) in the presence of $250 \mathrm{ng} / \mathrm{ml}$ Sema3A. Filled bars indicate addition of Sema3A. $\boldsymbol{E}$, In contrast, $1 \mu \mathrm{m}$ lysophosphatidic acid (LPA)-induced collapse is not affected by rapamycin. $\boldsymbol{F}, \boldsymbol{G}$, Protein synthesis dependence is not abolished by isolation of axons from the soma $(\boldsymbol{F})$, nor is the

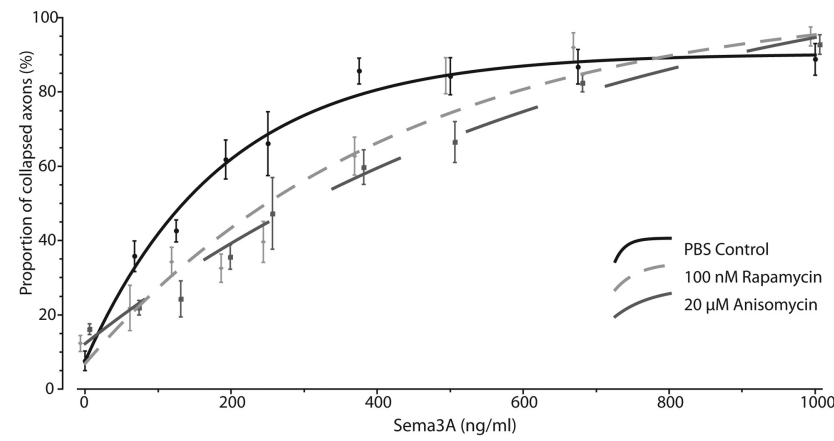

Figure 2. Protein synthesis dependence and adaptation to varying Sema $3 A$ concentrations The dose-response curve of axon growth cone collapse in the presence of $0-1000 \mathrm{ng} / \mathrm{ml}$ Sema3A, also in the presence of PBS control (continuous line), anisomycin (large dashes), or rapamycin (short dashes). Overlapping error bars are separated horizontally for greater clarity. With Sema 3 A concentrations in excess of $625 \mathrm{ng} / \mathrm{ml}$, the addition of anisomycin or rapamycin has no significant effect on growth cone collapse.

concentrations alongside activation of GSK-3 $\beta$ signaling, while at higher concentrations GSK- $3 \beta$ signaling becomes predominant.

\section{Materials and Methods}

F-12 medium, penicillin/streptomycin, and DMEM medium were sourced from PAA, and B27 supplement, L-15, phalloidin and Click-iT AHA Alexa Fluor 488 protein synthesis reagents from Invitrogen. Insulin/transferrin/selenite (ITS + 3), NGF, glutamine, laminin from mouse sarcoma, poly-L-lysine, lithium chloride, anisomycin, rapamycin, cycloheximide and L- $\alpha$-lysophosphatidic acid were purchased from Sigma-Aldrich, and dipotassium bisperoxo(picolinato)oxovanadate $(\mathrm{V})[\mathrm{bpV}(\mathrm{pic})]$ from Enzo Life Sciences. The GSK-3 $\beta$ inhibitor VIII (AR-A014418) was obtained from Calbiochem, and SB216763 from Tocris Bioscience. Sema3A-Fc and function-blocking antineuropilin-1 antibody were from R\&D Systems, and Borosilicate coverslips from VWR International.

Coverslips for explants of chick DRGs were cleaned in acid and ethanol, and flamed immediately before use. They were coated in $100 \mu \mathrm{g} / \mathrm{ml}$ poly-L-lysine for $1 \mathrm{~h}$ at $38^{\circ} \mathrm{C}$, and $20 \mu \mathrm{g} / \mathrm{ml}$ laminin for $1 \mathrm{~h}$. E7.5 DRGs were dissected in medium, grown overnight at $38^{\circ} \mathrm{C}$ in DMEM and NGF $\left(80 \mathrm{ng} / \mathrm{ml}\right.$ unless otherwise stated) in $5 \% \mathrm{CO}_{2}$. Anti-neuropilin-1 antibodies and PBS control were introduced to the medium $30 \mathrm{~min}$ before Sema3A. Inhibitors and inhibitor vehicle controls were introduced $1 \mathrm{~min}$ before Sema3A or $0.1 \%$ BSA/PBS vehicle controls, before cultures were incubated at $38^{\circ} \mathrm{C} / 5 \% \mathrm{CO}_{2}$ for $30 \mathrm{~min}$. Axonal transection was performed by removing the body of the ganglion using a cut glass pipette. Explants were fixed with $4 \% \mathrm{w} / \mathrm{v}$ formaldehyde, $15 \% \mathrm{w} / \mathrm{v}$ sucrose in PBS for $2 \mathrm{~h}$ at room temperature. Samples were blind-coded before levels of collapse were assessed by phase contrast microscopy; growth cones with two or fewer filopodia were considered collapsed (Fig. $1 \mathrm{~K}, L$, confirming equivalence of growth cone morphology when viewed by phase contrast and phalloidin staining). Data groups were compared using the nonparametric Mann-Whitney $U$ test and the Kruskal-Wallis ANOVA test; all percentage values are means. Growth cone numbers per data point average 150, minimum 50, taken from at least 3 cultures. Quantitative immunofluorescence was performed on the same cultures grown in 160 $\mathrm{ng} / \mathrm{ml}$ NGF (a high concentration to maintain a spread growth cone morphology in all samples so that comparative measurements could be

residual collapse abolished by combining protein synthesis inhibitors $(\boldsymbol{G})$. $\boldsymbol{H}$, Levels of growth cone protein synthesis fall to undetectable levels after application of each inhibitor. $I$, Using a lower concentration of NGF $(10 \mathrm{ng} / \mathrm{ml})$ collapse induced by $250 \mathrm{ng} / \mathrm{ml} \mathrm{Sema3A}$ is also inhibited by anisomycin.J, Combining $500 \mathrm{ng} / \mathrm{ml} \mathrm{Sema3A}$ and $10 \mathrm{ng} / \mathrm{ml} \mathrm{NGF}$ reduces the effect of protein synthesis inhibition to a nonsignificant level. $\boldsymbol{K}, \boldsymbol{L}$, Phase-contrast and fluorescence images of phalloidin-stained collapsed $(\boldsymbol{K})$ and spread $(\boldsymbol{L})$ growth cones. Scale bar, $5 \mu \mathrm{m} .{ }^{*} p<0.05$; ${ }^{* *} p<0.01 ;{ }^{* *} p<0.001 ;$ ns, not significant. 
A

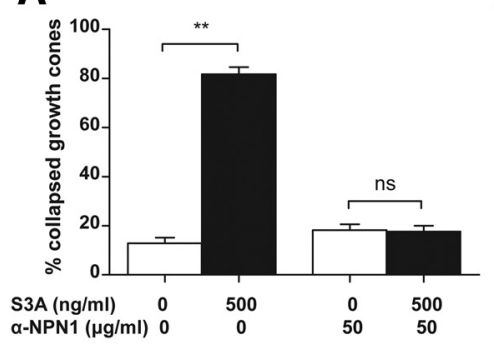

C

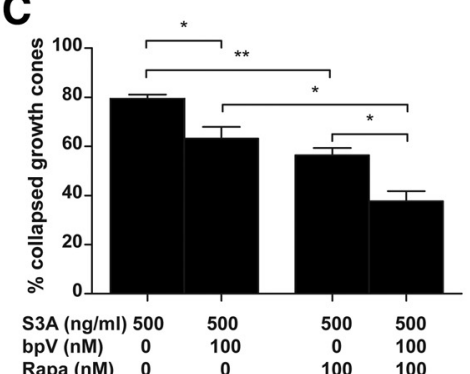

E
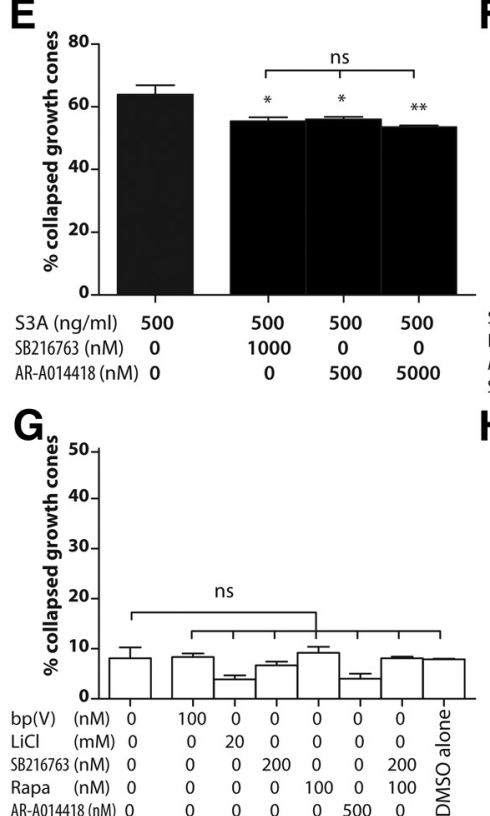

I

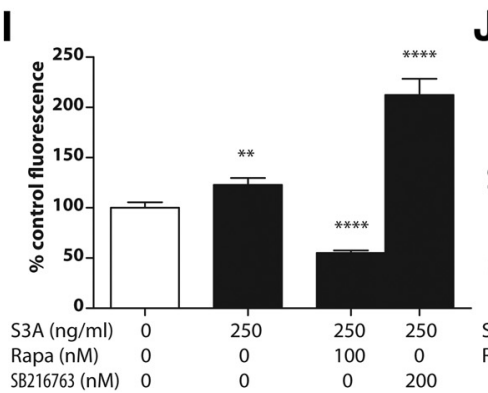

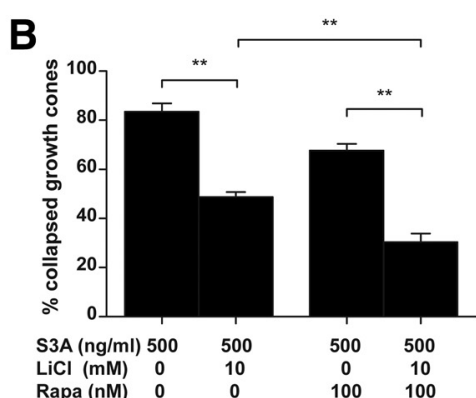

D

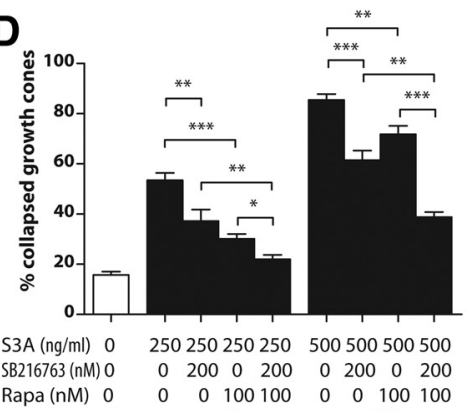

$\mathbf{F}$

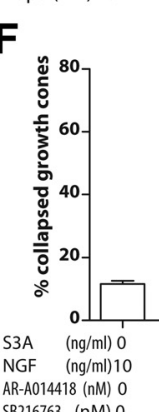

$216763(\mathrm{nM}) 0$

H

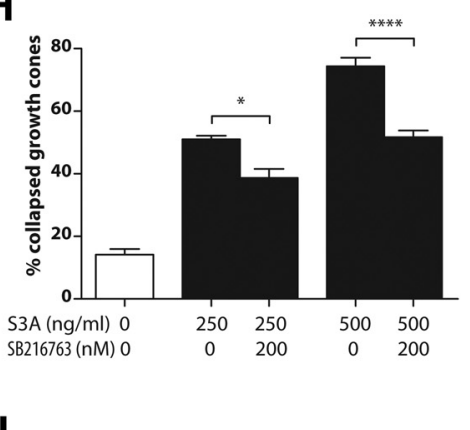

$\mathrm{J}$

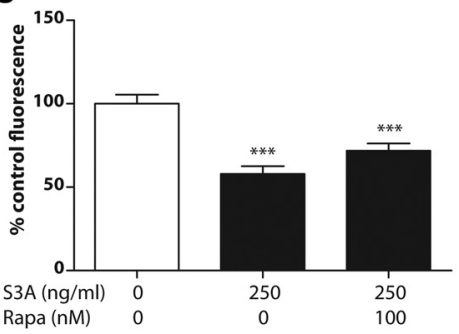

Figure 3. Assessment of pathways downstream of Sema-3A. $\boldsymbol{A}$, Addition of a neutralizing anti-neuropilin-1 antibody ( $\alpha$ NPN-1, $50 \mu \mathrm{g} / \mathrm{ml}$ ) abolishes growth cone collapse induced by $500 \mathrm{ng} / \mathrm{ml}$ Sema-3A (S3A). B, Inhibition of GSK-3 $\beta$ by lithium chloride (LiCl, $10 \mathrm{~mm}$ ) reduces collapse, and the effect is additive with rapamycin. C, Inhibition of PTEN by bpV(pic) (100 nm) is also additive with rapamycin-induced inhibition of collapse. $D$, The effect of GSK3- $\beta$ inhibition is confirmed at two different Sema-3A concentrations ( $250 \mathrm{ng} / \mathrm{ml}$ and $500 \mathrm{ng} / \mathrm{ml})$ using the selective GSK-3 $\beta$ inhibitor SB216763 (200 nM), and is additive with rapamycin. $\boldsymbol{E}$, A higher concentration of SB216763 (1000 nM) and another selective GSK-3 $\beta$ inhibitor, AR-014418 (0.5 $\mu \mathrm{m}$ and $5 \mu \mathrm{m})$, also inhibit Sema-3A-induced growth cone collapse. $F$, Using a lower NGF concentration ( $10 \mathrm{ng} / \mathrm{ml})$, collapse induced by both low and high Sema3A concentrations $(250 \mathrm{ng} / \mathrm{ml}, 700 \mathrm{ng} / \mathrm{ml})$ is approximately halved by SB216763 (200 nm) or AR-A014418 (0.5 $\mu \mathrm{m})$

made; Dontchev and Letourneau, 2002; Wu et al., 2005). Antibodies used were 1:100 anti-p4 EBP1 antibody or anti-pGSK-3 $\beta$ (Cell Signaling Technology), and Alexa Fluor 594 secondary antibodies. Inhibition of PS in growth cones was monitored using the Click-iT AHA Alexa Fluor 488 protein synthesis assay following manufacturer's instructions.

\section{Results}

PS inhibitors reduce, but do not eliminate, Sema3A-induced axon growth cone collapse

In our initial experiments we added PS inhibitors concurrently with Sema3A-Fc to chick DRG axons growing in DMEM with insulin/transferrin, glutamine and NGF $(80 \mathrm{ng} / \mathrm{ml})$. We found that 250 $\mathrm{ng} / \mathrm{ml}$ Sema3A induced $\sim 50 \%$ mean growth cone collapse after $30 \mathrm{~min}$, equivalent to one "collapsing unit" (Luo et al., 1993 ), as opposed to $\sim 10 \%$ collapse in PBS (control). Application of $25 \mu \mathrm{M}$ cycloheximide, a concentration sufficient to inhibit PS (see below), marginally yet significantly increased collapse versus control to $17 \%(p<0.05)$, but when applied concurrently with Sema3A collapse fell from $\sim 50 \%$ to $28 \%$ (Fig. $1 A$, $p<0.001)$. Despite PS blockade, 250 $\mathrm{ng} / \mathrm{ml}$ Sema3A still increased growth cone collapse relative to cycloheximide alone $(p<0.05)$.

As cycloheximide can increase cAMP levels (Liu et al., 2010), the experiment was repeated using $5 \mu \mathrm{M}$ anisomycin (Fig. $1 B)$. Anisomycin alone did not induce significant collapse, but when applied concurrently with Sema3A collapse levels fell from $45 \%$ to $18 \%$ ( $p<0.0001)$. The experiment was repeated using $40 \mu \mathrm{M}$ anisomycin (Fig. 1C), which alone induced $22 \%$ collapse, significantly higher than PBS control $(p<0.01)$. Despite this increase, Sema3A-induced collapse was inhibited by anisomycin $(p<0.05)$. Last,

$\leftarrow$

$G$, Control experiment confirming growth cone collapse is not induced by inhibitors of PTEN [bp(V)pic, $100 \mathrm{~nm}$ ] and GSK-3 $\beta$ (lithium chloride, LiCl, 20 mm; SB216763, 200 nm; AR-014418, $0.5 \mu \mathrm{M})$, nor by the combination of rapamycin and SB216763, nor by DMSO at the solvent concentration used for the latter reagents. $\boldsymbol{H}$, Control experiment confirming that the GSK-3 $\beta$ inhibitor SB216763 reduces Sema3A-induced collapse of growth cones of transected axons. I, Phosphorylation of 4EBP1 (\% control fluorescence) increases with application of Sema3A $(250 \mathrm{ng} / \mathrm{ml})$. It is further increased by addition of SB216763 (200 nM), and reduced below control levels by addition of rapamycin (100 nM). J, Phosphorylation of GSK-3 $\beta$ (\% control fluorescence) falls with Sema- $3 \mathrm{~A}(250 \mathrm{ng} / \mathrm{ml})$, and is not significantly altered by addition of rapamycin (100 nM). Error bars are SEM. ${ }^{*} p<0.05 ;{ }^{* *} p<0.01 ;{ }^{* * *} p<0.001$; ns, not significant. 
we found that $100 \mathrm{~nm}$ rapamycin (Fig. 1D), an inhibitor of mTOR, produced minimal collapse compared with controls $(8 \%$ vs $5 \%$ respectively, $p<0.05)$, and also reduced Sema3A-induced collapse from $41 \%$ to $16 \%$ ( $p<0.0001)$. In contrast, collapse induced by $1 \mu \mathrm{M}$ lysophosphatidic acid, a repulsive cue unaffected by PS inhibition (Campbell and Holt, 2001), was not reduced by rapamycin ( $49 \%$ vs $53 \%, p<0.05$; Fig. $1 E$ ).

To confirm the independence of PS-dependent collapse from the neuronal nucleus, we repeated the assays on axons severed from their cell bodies before Sema3A application (Fig. $1 F$ ). We also confirmed the presence of PS-independent collapse by combining application of cycloheximide and anisomycin (Fig. 1G). To check that any remaining Sema3A-induced collapse did not result from insufficient PS inhibition, PS was directly measured in growth cones by methionine substitution with azidohomoalanine (AHA) and labeling with tetramethylrhodamine in the presence of the inhibitors, and in the absence of AHA as a negative control. All three inhibitors significantly reduced fluorescence from control ( $p<0.001)$, to levels indistinguishable from the AHA-free negative control (Fig. $1 \mathrm{H}$ ).

\section{Effect of PS-inhibition depends on relative Sema3A and NGF concentrations}

Our initial culture medium included $80 \mathrm{ng} / \mathrm{ml} \mathrm{NGF}$, whereas Roche et al. (2009) cultured explants in $10 \mathrm{ng} / \mathrm{ml} \mathrm{NGF}$. Lower NGF concentrations have been shown to increase Sema3Ainduced growth cone collapse levels (Dontchev and Letourneau, 2002). Consistent with this, addition of $250 \mathrm{ng} / \mathrm{ml} \mathrm{Sema} 3 \mathrm{~A}$ in the presence of $10 \mathrm{ng} / \mathrm{ml} \mathrm{NGF}$ caused more collapse than in $80 \mathrm{ng} / \mathrm{ml}$ NGF ( $87 \%$ vs $55 \%$ respectively; Fig. 1 I vs Fig. $1 C$ ). Collapse was again inhibited by addition of anisomycin at this Sema3A concentration (Fig. 1I), but at $500 \mathrm{ng} / \mathrm{ml} \mathrm{Sema3A}$ the effect of PSinhibition declined to a nonsignificant level (Fig. $1 \mathrm{~J}$ ).

Having further confirmed the equivalence of growth cone morphology when viewed by phase contrast and phalloidin staining (Fig. $1 K, L$ ), we assessed the degree of collapse induced by a range of Sema3A concentrations, from $67.5 \mathrm{ng} / \mathrm{ml}$ to $1000 \mathrm{ng} / \mathrm{ml}$, in the presence of $80 \mathrm{ng} / \mathrm{ml} \mathrm{NGF}$ and $20 \mu \mathrm{M}$ anisomycin or 100 nM rapamycin using the same batches of Sema3A and NGF for each experiment (Fig. 2). Both anisomycin and rapamycin reduced the extent of growth cone collapse induced by Sema3A concentrations ranging from $67.5 \mathrm{ng} / \mathrm{ml}$ to $625 \mathrm{ng} / \mathrm{ml}(p<0.05)$, but with higher Sema3A concentrations neither inhibitor reduced collapse. The effects of rapamycin and anisomycin were broadly similar at all Sema3A concentrations studied. The overall position and shape of the dose-response curve was similar when independent batches of Sema3A and NGF were tested together (from the same suppliers; data not shown).

\section{Growth cone collapse involves the GSK-3 $\beta$ pathway at both low and high Sema3A concentrations}

We first confirmed the extent of neuropilin-1 involvement in Sema3A-induced collapse by incubating DRG explants in neutralizing anti-neuropilin-1 antibodies for $30 \mathrm{~min}$ before Sema3A addition (Fig. 3A). While $500 \mathrm{ng} / \mathrm{ml} \mathrm{Sema3A}$ alone induced $82 \%$ collapse, the antibody reduced collapse to control levels, confirming that Sema3A-induced collapse requires functional neuropilin-1.

GSK- $3 \beta$ activity is required for Sema3A-induced growth cone collapse (Eickholt et al., 2002), and we examined its relationship with mTOR-dependent collapse. Inhibition of GSK-3 $\beta$ activity with $10 \mathrm{~mm}$ lithium chloride reduced collapse induced by 500 $\mathrm{ng} / \mathrm{ml} \mathrm{Sema3A}$ ( $83 \%$ vs $49 \%, p<0.01$ ), confirming the role for

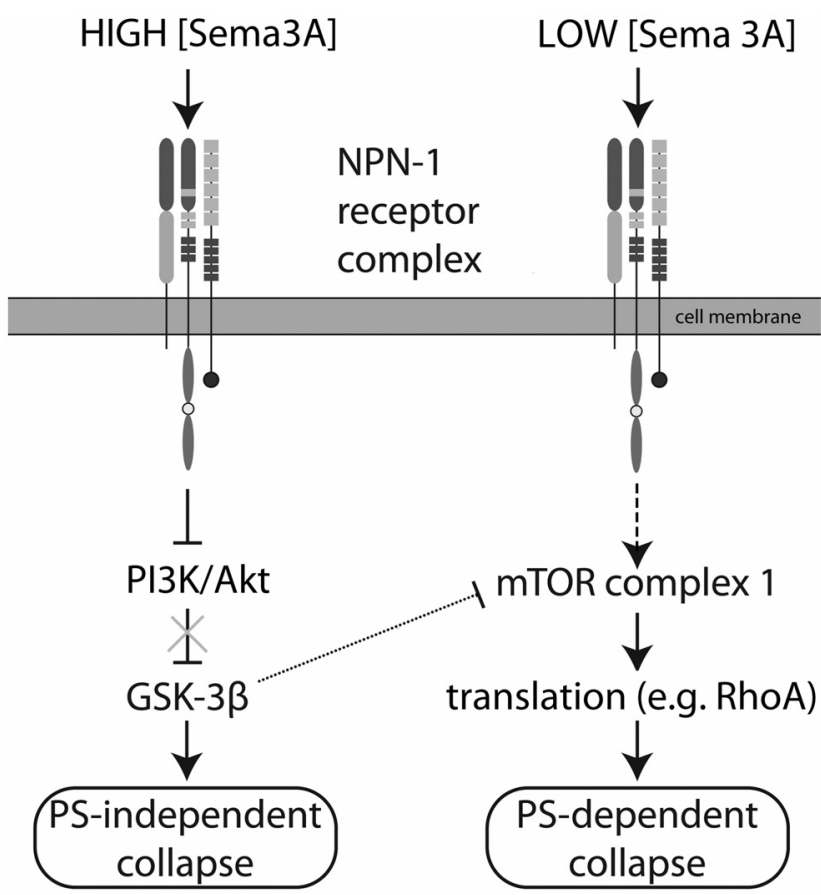

Figure 4. Schematic of proposed pathways mediating PS-dependent and PS-independent growth cone collapse in response to high/low Sema3A concentrations.

GSK-3 $\beta$ in Sema3A signaling (Fig. $3 B$ ). This reduction summated with that due to rapamycin when both inhibitors were present (Fig. 3B). Moreover, the reduction caused by inhibiting PTEN upstream of GSK-3 $\beta$ with $100 \mathrm{~nm} \mathrm{bpV}$ (pic) also summated with that of rapamycin (Fig. $3 C$ ). We further tested additional specific inhibitors of GSK-3 $\beta$ (SB216763 and ARA014418). In the presence of $250 \mathrm{ng} / \mathrm{ml}$ or $500 \mathrm{ng} / \mathrm{ml} \mathrm{Sema} 3 \mathrm{~A}$ and $80 \mathrm{ng} / \mathrm{ml}$ NGF, the combination of SB 216763 and rapamycin reduced collapse more than either alone (Fig. $3 D$ ). In the presence of $500 \mathrm{ng} / \mathrm{ml}$ Sema3A neither an increased concentration of SB216763 nor the inhibitor AR-A014418 reduced collapse further (Fig. 3E). In the presence of a lower NGF concentration (10 $\mathrm{ng} / \mathrm{ml}$ ) collapse was approximately halved by SB216763 and ARA014418 at both low and high Sema3A concentrations (250 ng/ $\mathrm{ml}, 700 \mathrm{ng} / \mathrm{ml}$; Fig. $3 F$ ). These experiments indicate a significant role for GSK-3 $\beta$ activity independently of the mTOR pathway. Control experiments confirmed that the GSK- $3 \beta$ inhibitors did not induce collapse in the absence of Sema3A (Fig. 3G), and that SB216763 reduced collapse to the same extent in transected and intact axons (Fig. $3 H$ ).

Last, we examined the activation and interaction of the mTOR and GSK- $3 \beta$ pathways more directly by quantitative immunofluorescence analysis of growth cones (Fig. $3 I, J)$. Application of $250 \mathrm{ng} / \mathrm{ml} \mathrm{Sema3A}$ increased p-4E-BP1 fluorescence $(p<$ 0.05 ) within $1 \mathrm{~h}$, indicating mTOR activation (Fig. 3I). Consistent with this, application of rapamycin with Sema3A reduced p-4E-BP1 fluorescence below control levels $(p<$ 0.0001 ). Conversely however, application of SB216763 with Sema3A significantly increased fluorescence above control (Fig. $3 I$ ), suggesting that GSK-3 $\beta$ activity is antagonistic to mTOR activation in this system. Moreover, while application of $250 \mathrm{ng} / \mathrm{ml}$ Sema3A reduced growth cone pGSK-3 $\beta$ fluorescence, indicating GSK-3 $\beta$ activation as expected, this response was refractory to rapamycin (Fig. $3 \mathrm{~J}$ ). 


\section{Discussion}

Sema3A is one of several guidance cues that have been linked to induction of rapid PS and degradation (Campbell and Holt, 2001; Brunet et al., 2005; Wu et al., 2005; Leung et al., 2006; Li et al., 2009). However, the role of PS within the growth cone has been controversial, particularly regarding its necessity for outgrowth and guidance (Eng et al., 1999; Campbell and Holt, 2001; Piper and Holt, 2004; Wu et al., 2005; van Kesteren et al., 2006; Roche et al., 2009). To resolve apparent differences between laboratories we have reinvestigated the role of local PS in Sema3Ainduced growth cone collapse. Our data show that three PS inhibitors reduce, but do not eliminate, Sema3A-induced collapse, and both reductions in NGF concentration and increases in Sema3A concentration amplify the PS-independent response. These findings suggest the presence of at least two pathways for Sema3A-induced collapse, which at concentrations $>500 \mathrm{ng} / \mathrm{ml}$ produce maximal collapse levels, and which function cooperatively across a wide concentration range. Our data indicate that the PS-dependent pathway is relatively more active at lower Sema3A concentrations. This model accounts for the findings of Campbell and Holt (2001), where mTOR inhibition blocked turning and collapse responses of Xenopus retinal axon growth cones to Sema3A almost to base-line levels, and those of Roche et al. (2009) who used a low concentration $(10 \mathrm{ng} / \mathrm{ml})$ of NGF. Moreover, Nédelec et al. (2012) have shown that while certain motor neuron subtypes are more susceptible to PS-dependent Sema3A-induced collapse than others, all tested subtypes undergo PS-independent collapse in the presence of high Sema3A concentrations. A similar concentration-dependence of PSinhibition has also been noted in mammalian (mouse) DRG growth cones (Li et al., 2004).

Neuropilin-1 is a Sema3A co-receptor that binds to plexins A1-4 (Takahashi et al., 1999) and L1 (Castellani et al., 2000). As anti-neuropilin-1 antibodies reduced collapse to control levels, collapse-inducing pathways must require neuropilin-1 and its binding partners. The GSK-3 $\beta$ pathway is involved in plexindependent collapse (Eickholt et al., 2002; Chadborn et al., 2006), and our data indicate that this is PS-independent. Thus GSK-3 $\beta$ inhibition with lithium chloride not only reduced Sema3Ainduced collapse, but its combination with rapamycin reduced collapse further than either agent alone. The residual collapse over control levels, also seen using combinations of SB216763/ rapamycin (Fig. 3D) and cycloheximide/anisomycin (Fig. 1G), and at high Sema3A concentrations in the presence of GSK-3 $\beta$ inhibitors (Fig. $3 E, F$ ), may be attributable to the operation of further GSK-3 $\beta$ - and mTOR-independent pathways. We further note that different collapse levels are sometimes obtained using the same reagent concentrations in separate experiments. This is likely to be caused by inevitable biological variation between different DRG cultures and by batch variation in Sema3A bioactivity.

Examination of GSK- $3 \beta$ and $4 \mathrm{E}-\mathrm{BP} 1$ phosphorylation levels, as reporters respectively of the GSK-3 $\beta$ - and mTOR-dependent pathways (Goode et al., 1992; Gingras et al., 1999), showed that while mTOR inhibition did not influence GSK-3 $\beta$ activation, GSK-3 $\beta$ inhibition promoted mTOR activity. This suggests that the GSK- $3 \beta$ pathway may regulate $\mathrm{mTOR}$ in the growth cone, but not vice versa. A similar GSK-3 $\beta /$ mTOR antagonism has also been identified in the Wnt signaling pathway (Inoki et al., 2006). Since GSK-3 $\beta$ activity dominates at high Sema3A concentrations, growth cone mTOR activity may be correspondingly reduced. Moreover, as NGF has been shown to inhibit GSK-3 $\beta$ activity (Zhou et al., 2004), the combination of high Sema3A and low NGF levels may activate GSK-3 $\beta$ signaling sufficiently to prevent mTOR activation by Sema3A (see Figs. $1 \mathrm{~J}, 4$ ). It will be interesting to assess these possibilities experimentally.

While it is unknown how these two pathways are deployed relatively during neural development in vivo, we can speculate that different neuronal subtypes may respond through either one or both of these pathways (Fig. 4). There is evidence, for example, that Sema3A-responsive neurons differ according to whether neuropilin-1 associates with a plexin-A or L1, and in the downstream consequences (Bechara et al., 2008). The possibility of divergent Sema3A signaling pathways also has the attraction of explaining apparent contradictions in studies showing that RhoA activity is either critical for Sema3A repulsive guidance (Wu et al., 2005) or not (Jin and Strittmatter, 1997). A similar divergence has been shown to mediate inductive specification or axon repulsion of developing neurons in response, respectively, to high or low BMP7 concentrations (Perron and Dodd, 2011), and could also underlie the concentration-dependent responsiveness of retinal axon growth cones to ephrin-A2 (Hansen et al., 2004).

We suggest that combinations of mTOR-dependent and mTOR-independent signaling pathways may facilitate axon navigation using adaptive responses (Piper et al., 2006), sharpening responsivity to repulsive gradients of the same guidance cue. Simultaneously this would enable high concentrations of repulsive molecules to define "no-go" areas prohibiting entry, for example, to Xenopus caudal tectum by retinal axons. Thus, the concentration-dependent activation of distinct signaling pathways can increase the information content of a single cue and may contribute to the general mechanism of cue-mediated axon behavior in vivo.

\section{References}

Andreassi C, Zimmermann C, Mitter R, Fusco S, De Vita S, Saiardi A, Riccio A (2010) An NGF-responsive element targets myo-inositol monophosphatase-1 mRNA to sympathetic neuron axons. Nat Neurosci 13:291-301.

Aronov S, Aranda G, Behar L, Ginzburg I (2001) Axonal tau mRNA localization coincides with tau protein in living neuronal cells and depends on axonal targeting signal. J Neurosci 21:6577-6587.

Bassell GJ, Zhang H, Byrd AL, Femino AM, Singer RH, Taneja KL, Lifshitz LM, Herman IM, Kosik KS (1998) Sorting of $\beta$-actin mRNA and protein to neurites and growth cones in culture. J Neurosci 18:251-265.

Bechara A, Nawabi H, Moret F, Yaron A, Weaver E, Bozon M, Abouzid K, Guan JL, Tessier-Lavigne M, Lemmon V, Castellani V (2008) FAKMAPK-dependent adhesion disassembly downstream of L1 contributes to semaphorin3A-induced collapse. EMBO J 27:1549-1562.

Bourne JN, Harris KM (2008) Balancing structure and function at hippocampal dendritic spines. Annu Rev Neurosci 31:47-67.

Brunet I, Weinl C, Piper M, Trembleau A, Volovitch M, Harris W, Prochiantz A, Holt C (2005) The transcription factor Engrailed-2 guides retinal axons. Nature 438:94-98.

Campbell DS, Holt CE (2001) Chemotropic responses of retinal growth cones mediated by rapid local protein synthesis and degradation. Neuron 32:1013-1026.

Castellani V, Chédotal A, Schachner M, Faivre-Sarrailh C, Rougon G (2000) Analysis of the L1-deficient mouse phenotype reveals cross-talk between Sema3A and L1 signaling pathways in axonal guidance. Neuron 27:237-249.

Chadborn NH, Ahmed AI, Holt MR, Prinjha R, Dunn GA, Jones GE, Eickholt BJ (2006) PTEN couples Sema3A signaling to growth cone collapse. J Cell Sci 119:951-957.

Donnelly CJ, Fainzilber M, Twiss JL (2010) Subcellular communication through RNA transport and localized protein synthesis. Traffic 11:1498-1505.

Dontchev VD, Letourneau PC (2002) Nerve growth factor and semaphorin $3 \mathrm{~A}$ signaling pathways interact in regulating sensory neuronal growth cone motility. J Neurosci 22:6659-6669. 
Eickholt BJ, Walsh FS, Doherty P (2002) An inactive pool of GSK-3 at the leading edge of growth cones is implicated in Semaphorin 3A signaling. J Cell Biol 157:211-217.

Eng H, Lund K, Campenot RB (1999) Synthesis of beta-tubulin, actin, and other proteins in axons of sympathetic neurons in compartmented cultures. J Neurosci 19:1-9.

Gingras AC, Gygi SP, Raught B, Polakiewicz RD, Abraham RT, Hoekstra MF, Aebersold R, Sonenberg N (1999) Regulation of 4E-BP1 phosphorylation: a novel two-step mechanism. Genes Dev 13:1422-1437.

Goode N, Hughes K, Woodgett JR, Parker PJ (1992) Differential regulation of glycogen synthase kinase- $3 \beta$ by protein kinase $\mathrm{C}$ isotypes. J Biol Chem 267:16878-16882.

Gumy LF, Yeo GS, Tung YC, Zivraj KH, Willis D, Coppola G, Lam BY, Twiss JL, Holt CE, Fawcett JW (2011) Transcriptome analysis of embryonic and adult sensory axons reveals changes in mRNA repertoire localization. RNA 17:85-98.

Hansen MJ, Dallal GE, Flanagan JG (2004) Retinal axon response to ephrin-As shows a graded, concentration-dependent transition from growth promotion to inhibition. Neuron 42:717-730.

Inoki K, Ouyang H, Zhu T, Lindvall C, Wang Y, Zhang X, Yang Q, Bennett C, Harada Y, Stankunas K, Wang CY, He X, MacDougald OA, You M, Williams BO, Guan KL (2006) TSC2 integrates Wnt and energy signals via a coordinated phosphorylation by AMPK and GSK3 to regulate cell growth. Cell 126:955-968.

Jin Z, Strittmatter SM (1997) Racl mediates collapsin-1-induced growth cone collapse. J Neurosci 17:6256-6263.

Kaplan BB, Gioio AE, Capano CP, Crispino M, Giuditta A (1992) betaActin and beta-Tubulin are components of a heterogeneous mRNA population present in the squid giant axon. Mol Cell Neurosci 3:133-144.

Leung KM, van Horck FP, Lin AC, Allison R, Standart N, Holt CE (2006) Asymmetrical beta-actin mRNA translation in growth cones mediates attractive turning to netrin-1. Nat Neurosci 9:1247-1256.

Li C, Sasaki Y, Takei K, Yamamoto H, Shouji M, Sugiyama Y, Kawakami T, Nakamura F, Yagi T, Ohshima T, Goshima Y (2004) Correlation between semaphorin3A-induced facilitation of axonal transport and local activation of a translation initiation factor eukaryotic translation initiation factor 4E. J Neurosci 24:6161-6170.

Li C, Bassell GJ, Sasaki Y (2009) Fragile X mental retardation protein is involved in protein synthesis-dependent collapse of growth cones induced by semaphorin-3A. Front Neural Circuits 3:11.

Lin AC, Holt CE (2007) Local translation and directional steering in axons. EMBO J 26:3729-3736.

Liu X, Yang JM, Zhang SS, Liu XY, Liu DX (2010) Induction of cell cycle arrest at G1 and S phases and cAMP-dependent differentiation in C6 glioma by low concentration of cycloheximide. BMC Cancer 10:684.

Luo Y, Raible D, Raper JA (1993) Collapsin: a protein in brain that induces the collapse and paralysis of neuronal growth cones. Cell 75:217-227.
Martin KC, Zukin RS (2006) RNA trafficking and local protein synthesis in dendrites: an overview. J Neurosci 26:7131-7134.

Nédelec S, Peljto M, Shi P, Amoroso MW, Kam LC, Wichterle H (2012) Concentration-dependent requirement for local protein synthesis in motor neuron subtype-specific response to axon guidance cues. J Neurosci 32:1496-1506.

Park KK, Liu K, Hu Y, Smith PD, Wang C, Cai B, Xu B, Connolly L, Kramvis I, Sahin M, He Z (2008) Promoting axon regeneration in the adult CNS by modulation of the PTEN/mTOR pathway. Science 322:963-966.

Perron JC, Dodd J (2011) Inductive specification and axonal orientation of spinal neurons mediated by divergent bone morphogenetic protein signaling pathways. Neural Dev 6:36.

Piper M, Holt C (2004) RNA translation in axons. Annu Rev Cell Dev Biol 20:505-523.

Piper M, Anderson R, Dwivedy A, Weinl C, van Horck F, Leung KM, Cogill E, Holt C (2006) Signaling mechanisms underlying Slit2-induced collapse of Xenopus retinal growth cones. Neuron 49:215-228.

Roche FK, Marsick BM, Letourneau PC (2009) Protein synthesis in distal axons is not required for growth cone responses to guidance cues. J Neurosci 29:638-652.

Sasaki Y, Welshhans K, Wen Z, Yao J, Xu M, Goshima Y, Zheng JQ, Bassell GJ (2010) Phosphorylation of zipcode binding protein 1 is required for brain-derived neurotrophic factor signaling of local beta-actin synthesis and growth cone turning. J Neurosci 30:9349-9358.

Schuman EM, Dynes JL, Steward O (2006) Synaptic regulation of translation of dendritic mRNAs. J Neurosci 26:7143-7146.

Takahashi T, Fournier A, Nakamura F, Wang LH, Murakami Y, Kalb RG, Fujisawa H, Strittmatter SM (1999) Plexin-neuropilin-1 complexes form functional semaphorin-3A receptors. Cell 99:59-69.

Taylor AM, Berchtold NC, Perreau VM, Tu CH, Jeon NL, Cotman CW (2009) Axonal mRNA in uninjured and regenerating cortical mammalian axons. J Neurosci 29:4697-4707.

van Kesteren RE, Carter C, Dissel HM, van Minnen J, Gouwenberg Y, Syed NI, Spencer GE, Smit AB (2006) Local synthesis of actin-binding protein beta-thymosin regulates neurite outgrowth. J Neurosci 26:152-157.

Wu KY, Hengst U, Cox LJ, Macosko EZ, Jeromin A, Urquhart ER, Jaffrey SR (2005) Local translation of RhoA regulates growth cone collapse. Nature 436:1020-1024.

Yao J, Sasaki Y, Wen Z, Bassell GJ, Zheng JQ (2006) An essential role for beta-actin mRNA localization and translation in $\mathrm{Ca} 2+$-dependent growth cone guidance. Nat Neurosci 9:1265-1273.

Zhou FQ, Zhou J, Dedhar S, Wu YH, Snider WD (2004) NGF-induced axon growth is mediated by localized inactivation of GSK-3beta and functions of the microtubule plus end binding protein APC. Neuron 42:897-912.

Zivraj KH, Tung YC, Piper M, Gumy L, Fawcett JW, Yeo GS, Holt CE (2010) Subcellular profiling reveals distinct and developmentally regulated repertoire of growth cone mRNAs. J Neurosci 30:15464-15478. 